Mariana Mouraz LoPes dos Santos ${ }^{1}$

Sara Marques Soares Proença ${ }^{1}$

Maria INÊs Nunes Pereira de Almeida Reis

Rui Miguel Almeida Lopes Viana ${ }^{1}$

LuÍSA Maria Bernardo Martins ${ }^{1}$

João Manuel dos Reis Colaço'

Filomena Maria PinheIRO NunES ${ }^{1}$

Case Report

Keywords

Angiomyolipoma/complications Angiomyolipoma/diagnosis Pregnancy complications, neoplastic

Rupture, spontaneous Case reports

Palavras-chave

Angiomiolipoma/complicações Angiomiolipoma/diagnóstico Complicações neoplásicas na gravidez Ruptura espontânea Relatos de casos

Correspondence

Mariana Mouraz Lopes dos Santos Avenida Brigadeiro Victor Novais Gonçalves, 2755-009 - Alcabideche

Cascais, Portugal

Received

07/05/2014

Accepted with modifications

07/07/2014

\section{Spontaneous rupture of renal angiomyolipoma during pregnancy}

\section{Rotura espontânea de um angiomiolipoma durante a gravidez}

\section{Abstract}

Renal angiomyolipoma is a benign tumor, composed of adipocytes, smooth muscle cells and blood vessels. The association with pregnancy is rare and related with an increased risk of complications, including rupture with massive retroperitoneal hemorrhage. The follow-up is controversial because of the lack of known cases, but the priorities are: timely diagnosis in urgent cases and a conservative treatment when possible. The mode of delivery is not consensual and should be individualized to each case. We report a case of a pregnant woman with 18 weeks of gestation admitted in the emergency room with an acute right low back pain with no other symptoms. The diagnosis of rupture of renal angiomyolipoma was established by ultrasound and, due to hemodinamically stability, conservative treatment with imaging and clinical monitoring was chosen. At 35 weeks of gestation, it was performed elective cesarean section without complications for both mother and fetus.

\section{Resumo}

angiomiolipoma é um tumor benigno, constituído por adipócitos, células de músculo liso e vasos sanguíneos. Sua associação com a gravidez é rara e está relacionada com um aumento de complicações, nomeadamente rotura com hemorragia retroperitoneal maciça. $\bigcirc$ follow-up é controverso em razão do escasso número de casos descritos, no entanto as prioridades são: diagnóstico atempado nas situações urgentes e, sempre que possível, tratamento conservador. $\bigcirc$ tipo de parto não é consensual e deve ser individualizado caso a caso. Relatamos um caso de uma grávida com 18 semanas de gestação que recorreu ao serviço de urgência por lombalgia direita aguda, sem outros sintomas relevantes. Diagnosticou-se ecograficamente rotura de angiomiolipoma renal e, em decorrência da estabilidade hemodinâmica do quadro, procedeu-se ao tratamento conservador com monitorização imagiológica e clínica. Às 35 semanas de gestação, realizou-se uma cesariana eletiva que decorreu sem complicações maternas ou fetais.
'Department of Obstetrics and Gynecology, Hospital Dr. José de Almeida - Cascais, Portugal. Conflict of interests: none. 


\section{Introduction}

The angiomyolipoma (AML) is often a benign tumor consisting of three types of histologic features: adipocytes, smooth muscle cells and blood vessels with thickened wall ${ }^{1-3}$. The incidence of renal AML is $0.3 \%$ in the general population and represents $3 \%$ of solid renal masses ${ }^{1-4}$, being even more infrequent during pregnancy ${ }^{1,4-6}$. There are two known types of AML: the isolated angiomyolipoma, which represents $80 \%$ of cases, and the one associated with tuberous sclerosis (TS $)^{1,7,8}$. In the first case, these masses are usually solitary, large and asymptomatic, and the mean age of diagnosis is 43 years ${ }^{1,4,7}$. When associated with TS are often multiple, bilateral and small, and hemorrhage is frequent ${ }^{8}$. The diagnosis is made at earlier ages, 20-30 years ${ }^{1,2,8}$. As in most cases there are no symptomatic manifestations ${ }^{1,2}$, the AMLs are often diagnosed as incidentalomas ${ }^{1,4}$, however they may be related to severe symptoms ${ }^{9-12}$.

The risk of spontaneous rupture associated with pregnancy is higher and can be catastrophic ${ }^{5,7}$. A conservative approach, with preservation of renal function by selective embolization or partial nephrectomy, is possible and preferable in most patients ${ }^{2,4,5,13}$.

\section{Case report}

TM, 40 years old, gesta 3, para 2, current pregnancy through in vitro fertilization, had two transverse segmental cesarean sections in 2000 and 2003. Patient had no relevant family history.

The pregnancy proceeded without complications until 18 weeks of gestation, when appeared a low back pain radiating to right upper abdominal quadrant, with no other associated symptoms. On physical and analytical examination, it was found a positive renal Murphy sign, microscopic hematuria, hemoglobin of $10.8 \mathrm{mg} / \mathrm{dL}$ and $5.82 \mathrm{mg} / \mathrm{dL}$ of C-reactive protein. In the ultrasound, a $5 \mathrm{~cm}$ nodular lesion in the right kidney was detected, what suggests anhyperechoic, heterogeneous AML, consistent with probable hemorrhage (Figure 1). The patient underwent only conservative measures, and the bleeding stopped spontaneously. Two months after the first ultrasound, a magnetic resonance imaging (MRI) was performed and there was no evidence of increasing (Figure 2). Regularity of the pain, which was frequent and progressively worsening, breech presentation and two previous cesarean-scars led to schedule a cesarean section for 35 weeks. The surgery was performed without any complications. Surgeons opted for a non exhaustive exploration of the retroperitoneal space due to the risk of rupture associated with handling. The 1 - and 5-minute ApgarApgar was 9 and 10, respectively, and the immediate

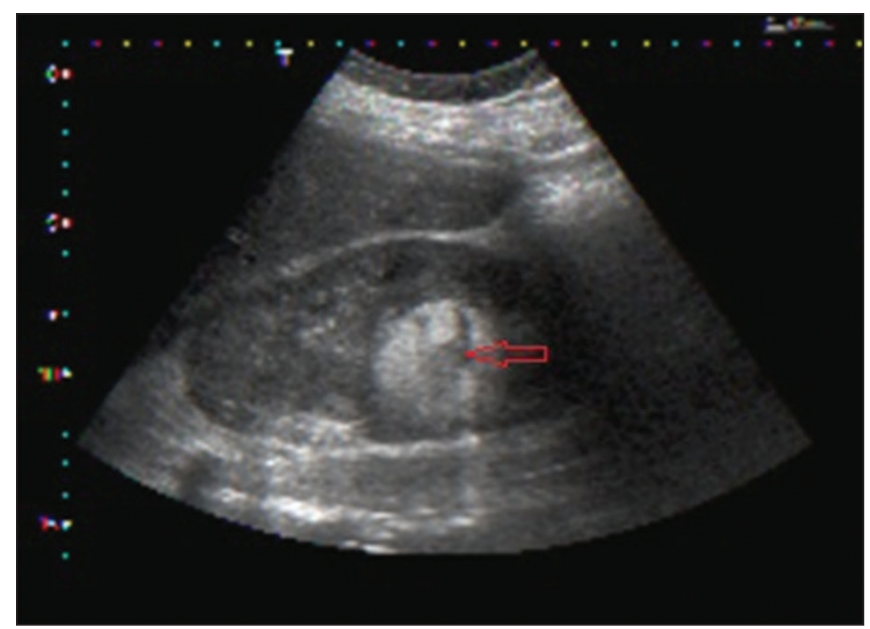

Figure 1. Renal ultrasound, nodular lesion with $5 \mathrm{~cm}$ suggestive of angiomyolipoma

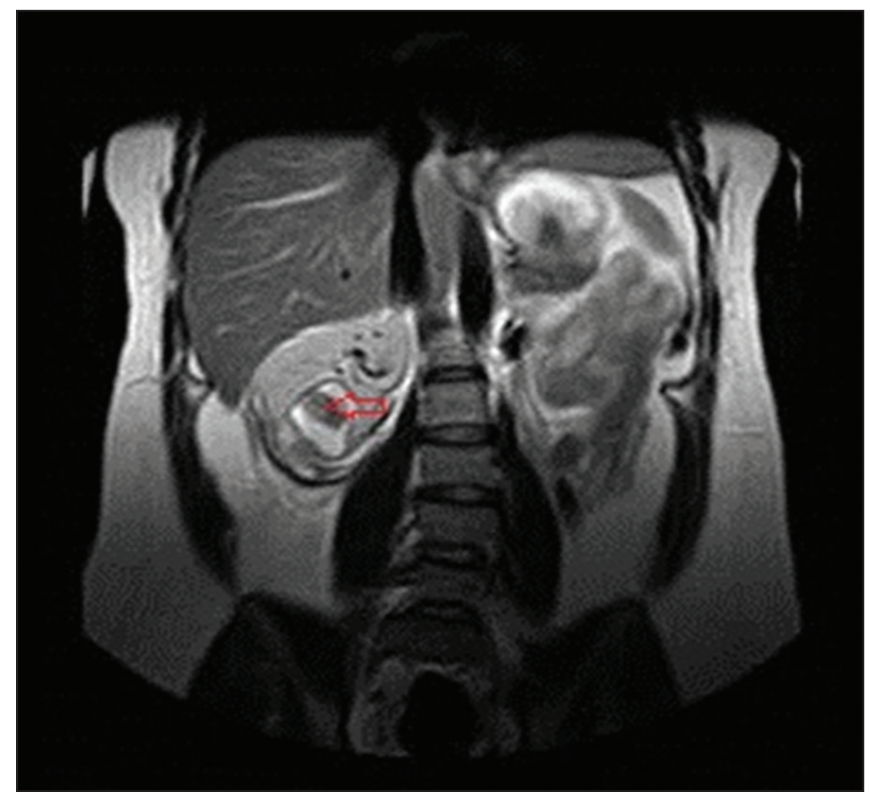

Figure 2. Abdominal magnetic resonance imaging, nodular lesion with 5 $\mathrm{cm}$ with hemorrhagic material and subcapsular hematoma

post-partum period went linear. The patient refused any surgical treatment and imaging follow-up postpartum.

\section{Discussion}

The AMLs are uncommon tumors ${ }^{14,15}$. They were first described in 1951 by Morgan et al.,3,14. Most of these tumors appear in the kidney (renal parenchyma), however these can be found in other locations, such as the spleen, liver, uterus and fallopian tubes ${ }^{14}$.

About $20 \%$ of the cases are associated with tuberous sclerosis, which is an autosomal dominant disease, rare, characterized by the growth of benign tumors in multiple organs (kidney, brain, heart, lungs and skin) ${ }^{16-18}$. Signs and symptoms depend on the affected organ and may have 
multiple levels of severity ${ }^{19}$. AMLs occur in $80 \%$ of the patients with $\mathrm{TS}^{4,8,14,18-21}$. The majority of the cases occur at earlier ages, present bilateral distribution, are usually multiple, small $(<2 \mathrm{~cm})$, benign and asymptomatic $\mathrm{c}^{4,7,14}$. These tend to grow faster when compared to the isolated type and often require earlier surgical treatment ${ }^{3,4,7,14}$. In cases that arise isolated, the tumor is usually single, unilateral, asymptomatic, appears later in life ${ }^{4,14}$, grows slowly and has better outcomes?

These tumors are usually asymptomatic, but can manifest as a flank pain, palpable abdominal mass, hematuria, nausea and vomiting ${ }^{1,3,14,20}$. In $10 \%$ of the cases, they manifest as hypovolemic shock resulting from massive retroperitoneal bleeding, known as Wunderlich syndrome ${ }^{1-3,14,21-23}$. The risk factors associated with the spontaneous rupture and perirenal or intratumoral bleeding, include: association with TS, signs and symptoms, a bigger size $(>4 \mathrm{~cm})$ and pregnancy ${ }^{14}$. The main causes in pregnancy are increased growth rate, blood volume and renal blood flow ${ }^{4,14,20}$. The greater growth during pregnancy, the predominance in women in childbearing age and the rarity before puberty suggest clear hormone dependence $e^{4,5,14,20}$.

Ultrasonographically, the tumor presents a hyperechoic mass with great vascularity - existence of arteriovenous shunts (turbulent pulsating flows) ${ }^{14}$. Computed tomography $(\mathrm{CT})$ is the gold standard exam because it detects fat in the tumor ${ }^{7}$ - highly suggestive of $\mathrm{AML}^{3,11}$. MRI can also differentiate fat by its high signal intensity and is a complementary exam currently used when CT is contraindicated and when lesions are small or complex ${ }^{14,16}$.

The main differential diagnosis must be established with renal cell carcinoma ${ }^{14}$. Other causes of retroperitoneal bleeding are: spontaneous rupture of kidney with hidronefrosis, spontaneous rupture of aneurysm or renal vessels and other vascular accidents ${ }^{9,14,20}$.

The follow-up of these patients is highly controversial and debatable due to the lack of known cases $^{1,4,14}$; however, in most situations, it is used an algorithm proposed by Oesterling, based on clinical, bilaterally and tumor size ${ }^{4,14}$. Asymptomatic tumors should be controlled with ultrasound or CT every six months if they are greater than $4 \mathrm{~cm}$ and once a year if they are smaller ${ }^{1,4,9,14}$. In symptomatic cases or with bilateral lesions, the choice should be selective arterial embolization or conservative renal surgery (lumpectomy or partial nephrectomy) ${ }^{1,4,14,21,24-27}$. Radical nephrectomy is performed in cases of urgency, with uncontrollable bleeding and hemodynamic instability, large tumor size, central location or coexisting carcinoma ${ }^{1,14,25}$. The rupture during pregnancy, in many instances, requires an urgent laparotomy in order to control bleeding, by nephrectomy ${ }^{14}$. Some authors recommend fetal extraction by cesarean section in the same surgical procedure in pregnancies at 28 gestational weeks or more ${ }^{14}$.

In our case, due to the hemodynamic stability and spontaneous cessation of bleeding it was decided to perform an expectant procedure, even though the tumor size was greater than $4 \mathrm{~cm}$.

As we have seen, it appears that these tumors have a higher growth rate in pregnancy, and the question that often arises is about the best time to perform surgery ${ }^{1,4}$. If there is an absolute necessity to perform surgery, the second trimester of pregnancy is chosen for the following reasons: surgery during the first trimester may increase the rate of abortions and fetal malformations, and in the third trimester there are more technical difficulties and the risk of pre-term delivery increases ${ }^{1,4,14}$

The delivery mode should be discussed case by case, depending on the coexistence of the associated factors ${ }^{14,28}$. Although it seemed that the variations in blood pressure during labor and Valsalva maneuvers could increase the risk of potentially fatal bleeding, there are no evidences that prove a higher incidence of bleeding during a vaginal delivery when compared to the cesarean procedure ${ }^{14}$.

In conclusion, we have to individualize each case, but always keep in mind the priorities: on-time diagnosis in urgent cases and the most conservative treatment as possible.

\section{References}

1. Kontos S, Politis V, Fokitis I, Lefakis G, Koritsiadis G, Simaioforidis $\mathrm{V}$, et al. Rapture of renal angiomyolipoma during pregnancy: a case report. Cases J. 2008; 1 (1):245.

2. Pereira S, Martinho D, Rodrigues R, Melo M, Mendonça T, Romão A, etal. Rotura espontânea de angiomiolipomarenal. ActaUrol. 2009;26(2):1 18.

3. Pinto AC, Campos RSM, Pereira DA, Gomes GC, Carnevale FC, Pinto AFC. [Renal angiomyolipomarupture: case report]. Einstein (São Paulo). 2006;4(1):25-6. Portuguese.
4. Gimeno Argente V, Bosquet Sanz M, Bonillo García MA, Gómez Pérez L, Pontones Moreno JL, Jiménez Cruz JF. Cirugía conservadora del angiomiolipoma renal bilateral durante el embarazo. Actas Urol Esp. 2006;30(6):633-7.

5. Zapardiel I, Delafuente-Valero J, Bajo-Arenas JM. Renal angiomyolipoma during pregnancy: review of the literature. Gynecol Obstet Invest. $2011 ; 72(4): 217-9$. 
6. Peces R, Cuesta-López E, Peces C, Selgas R. Giant bilateral renal angiomyolipomas and lymphangioleiomyomatosis presenting after two successive pregnancies successfully treated with surgery and rapamycin. Scientific World Journal. $2011 ; 11: 2115-23$

7. Lim $\mathrm{CH}$, Mulvin D. Embolisation of bleeding renal angiomyolipoma in pregnancy. Open J Urol. $2011 ; 1(3): 25-7$.

8. Ferianec V, Gábor M, Caňo M, Papcun P, Holomáň K. Severe retroperitoneal haemorrhage in the first trimester of a multiple pregnancy after spontaneous rupture of renal angiomyolipoma. Arch Gynecol Obstet. 2013;288(6):1193-4.

9. Lu $C Y, M i n P Q, W u B$. CT evaluation of spontaneously ruptured renal angiomyolipomas with massive hemorrhage spreading into multi-retroperitoneal fascia and fascial spaces. Acta Radiol Short Rep. 2012;1(4):arsr.2012.110009.

10. Wang HB, Yeh CL, Hsu KF. Spontaneous rupture renal angiomyolipoma with hemorrhagic shock. Intern Med. 2009;48(12):1111-2.

11. Cifuentes M, Calleja F, Hola J, Daviú A, Jara D, Vallejos H. [Renal angiomyolipoma rupture as a cause of lumbar pain: report of one case]. Rev Med Chil. 2008;136(8):1031-3. Spanish.

12. Unlü C, Lamme B, Nass $P$, Bolhuis HW. Retroperitoneal haemorrhage caused by a renal angiomyolipoma. Emerg Med J. $2006 ; 23(6): 464-5$

13. Shen WH, Pan JH, Yan JN, Chen ZW, Zhou ZS, Lu GS, et al. Resection of a giant renal angiomyolipoma in a solitary kidney with preoperative arterial embolization. Chin Med J (Engl). $2011 ; 124(9): 1435-7$

14. Illescas Molina T, Montalvo Montes J, Contreras Cecilia E, Muñoz Muñiz M, González González A, Herraiz Martínez M. Angiomiolipomas, esclerosis tuberosa y gestación: caso clínico. Ginecol Obstet Mex. 2009;77(8):380-6.

15. Itano S, Sakai T, ljuin H, Koga K, Yoshiyama Y, Yoshida T, et al. Three cases of renal angiomyolipoma. Intern Med. 1997;36(3):206-10.

16. Bigelow D, Folio L. Radiology corner. Angiomyolipoma. Mil Med. 2008; 173(1):xiii-xiv.
17. Schneider-Monteiro ED, Lucon AM, de Figueiredo AA, Rodrigues Junior AJ, Arap S. Bilateral giant renal angiomyolipoma associated with hepatic lipoma in a patient with tuberous sclerosis. Rev Hosp Clin Fac Med Sao Paulo. 2003;58(2): 103-8.

18. Kodama K, Takase Y, Motoi I. Management of a renal calculus larger than $4 \mathrm{~cm}$ in a patient with tuberous sclerosis complexassociated angiomyolipoma. Indian J Urol. 2012;28(4):442-4.

19. Prando A. Renal angiomyolipoma: relationships between tumor size, aneurysm formation, and rupture. Int Braz J Urol. 2002;28(6):578-9.

20. Lewis EL, Palmer JM. Renal angiomyolipoma and massive retroperitoneal hemorrhage during pregnancy. West J Med. $1985 ; 143(5): 675-6$.

21. Lee SY, Wang W, Yen TH, Chang CT. Transarterial embolization of ruptured angiomyolipoma associated with tuberous sclerosis. Nephrol Dial Transplant. 2005;20(8):1762-3.

22. Sparks D, Chase D, Thomas D, Arnott J. The Wunderlich's syndrome secondary to massive bilateral angiomyolipomas associated with advanced tuberous sclerosis. Saudi J Kidney Dis Transpl. 2011;22(3):534-7.

23. Medda M, Picozzi SC, Bozzini G, Carmignani L. Wunderlich's syndrome and hemorrhagic shock. J Emerg Trauma Shock. 2009;2(3):203-5.

24. Koo KC, Kim WT, Ham WS, Lee JS, Ju HJ, Choi YD. Trends of presentation and clinical outcome of treated renal angiomyolipoma. Yonsei Med J. 2010;51(5):728-34.

25. Kellner DS,Ercolani MC, Isom-Batz G, Javit DJ, Armenakas NA.Renal angiomyolipoma presenting with massive retroperitoneal hemorrhage. Hosp Physician. 2004;40(12):34-6.

26. Idilman IS, Vesnic S, Cil B, Peynircioglu B. Giant renal artery pseudoaneurysm caused by rupture of renal angiomyolipoma following pregnancy: endovascular treatment and review of the literature. Saudi J Kidney Dis Transpl. 2014;25(2):385-9.

27. Shah J, Jones J, Miller MA, Patel U, Anson KM. Selective embolization of bleeding renal angiomyolipoma in pregnancy. J R Soc Med. $1999 ; 92(8): 414-5$.

28. Tanaka $M$, Kyo $S$, Inove $M$, Kojima T. Conservative management and vaginal delivery following ruptured renal angiomyolipoma. Obstet Gynecol. 2001;98(5 P+ 2):932-3. 